\title{
Mammals of Con Son Island, southern Vietnam
}

\author{
Alexei V. Abramov*, Sergei V. Kruskop \& Anton V. Shchinov
}

\begin{abstract}
An inventory of the mammal fauna of the Con Son Island, the largest island of Con Dao Archipelago in southern Vietnam, has been conducted during the 2010 expedition of the Russian-Vietnam Tropical Centre. 17 species of terrestrial mammals are recorded based on trapped specimens and field observations. Relevant taxonomic notes, as well as distributional and habitat data, are provided for each reported species. An annotated list of terrestrial mammals of Con Son Island based on our field survey and a comparative analysis with the available literature data are presented.

How to cite this article: Abramov A.V., Kruskop S.V., Shchinov A.V. 2018. Mammals of Con Son Island, southern Vietnam // Russian J. Theriol. Vol.17. No.1. P.1-16. doi: 10.15298/rusjtheriol.17.1.01
\end{abstract}

KEY WORDS: mammals, Con Dao National Park, Vietnam.

AlexeiV.Abramov [alexei.abramov@zin.ru], Zoological Institute, Russian Academy of Sciences, Universitetskaya nab. 1, Saint Petersburg 199034, Russia; Joint Vietnam-Russian Tropical Research and Technological Centre, Nguyen Van Huyen, Nghia Do, Cau Giay, Hanoi, Vietnam; Sergei V. Kruskop [kruskop@zmmu.msu.ru], Zoological Museum, Moscow State University, ul. Bolshaya Nikitskaya 6, Moscow 125009, Russia; Joint Vietnam-Russian Tropical Research and Technological Centre, Nguyen Van Huyen, Nghia Do, Cau Giay, Hanoi, Vietnam; Anton V. Shchinov [schinovanton@mail.ru], A.N. Severtzov Institute of Ecology and Evolution, Russian Academy of Sciences, Leninskii pr. 33, Moscow 119071, Russia; Joint Vietnam-Russian Tropical Research and Technological Centre, Nguyen Van Huyen, Nghia Do, Cau Giay, Hanoi, Vietnam.

\section{Млекопитающие острова Коншон, южный Вьетнам}

\section{А.В. Абрамов, С.В. Крускоп, А.В. Щинов}

РЕЗЮМЕ. В 2010 г. во время экспедиции Российско-Вьетнамского Тропического центра была проведена инвентаризация фауны млекопитающих острова Коншон, крупнейшего острова архипелага Кондао, южный Вьетнам. По данным отловов и визуальных наблюдений было отмечено 17 видов наземных млекопитающих. Для каждого отмеченного вида приведены данные о местообитаниях и таксономические комментарии. Приведен аннотированный список наземных млекопитающих острова Кон Сон на основании собственных полевых исследований и анализа существующих литературных данных.

КЛЮЧЕВЫЕ СЛОВА: млекопитающие, национальный парк Кондао, Вьетнам.

\section{Introduction}

The Con Dao Archipelago (Ba Ria - Vung Tau Province) is located some $80 \mathrm{~km}$ of the continental part of southern Vietnam. Total surface area of the archipelago is ca. $150.43 \mathrm{~km}^{2}$. The archipelago includes 14 islands, of which the Con Son Island is the largest (ca. $51.5 \mathrm{~km}^{2}$ ). The main part of the island is occupied by forested hills and mountains, with the highest peak called Nui Chua (577 m a.s.1.).

The archipelago's location on the crucial marine route between East Asia and Malaysia and Indonesia results in frequent contacts with mariners from various nations (Hayward \& Giang Thuy Huu Tran, 2014). A number of early European travellers to eastern Asia visited the Con Son Island, previously known as Pulo Condore, with Marco Polo sheltering out a storm in the

\footnotetext{
* Corresponding author
}

islands in 1294. Later, in the 15th and 16th centuries, other European ships visited the island to obtain fresh water, fruits and meat from the local community.

The fauna and flora of these remote tropical islands have been attractive to researchers for long time. In Mr. William Ellis's drawing of the animals observed during Cook's third voyage, there is a figure and description of a Tupaia species, marked as coming from Pulo Condore (Gray, 1860). Many researchers who visited Pulo Condore and neighboring islands in the 19th century (e.g., George Finlayson, John Crawfurd and others) mentioned a poor mammal diversity of this archipelago (Kloss, 1921). Large and common animals were mostly recorded, such as monkeys, flying squirrels, black squirrels. At that time mammalian specimens from the Con Dao Archipelago were poorly presented in European museums. The first material was collected by the French army veterinarian Louis Rodolphe Germain who stayed in the Indochina in 1862-1867. Many species of birds 
and mammals of SE Asia were named after Mr. Germain, including such common species of Con Son Island as the black squirrel Sciurus germaini and the rat Mus germaini (see Milne-Edwards, 1867, 1872).

A good collection of vertebrate animals from the Con Dao Archipelago was assembled by the research team of Malcolm Smith (see Rozhnov, 1998). Malcolm Smith did not visit the archipelago by himself, but two of his collectors worked there and collected many specimens of birds, mammals, reptiles and amphibians. First scientific publications about the vertebrates of Con Son were based on these materials (Kloss, 1921; Robinson \& Kloss, 1921; Smith, 1921).

The most extensive collection of Con Son mammals was assembled by the medical-zoological group of US army in the spring of 1968 (Van Peenen et al., 1970). Besides large mammals (near 300 specimens of 18 species), which are now deposited in the Smithsonian Institution (Washington, USA, USNM), various ectoparasites (mites, fleas, and lice) were collected and studied (Hadi et al., 1977). Karyotypes of several common rodents were studied as well (Duncan et al., 1970, 1971). Over the next 40 years, no special mammalogical surveys have been conducted on the island. The Con Son Island and the neighboring small Bai Canh Island were visited by the expedition of the USSR Academy of Sciences in April 1987 for a short time (Darevsky et al., 1991; Kuznetsov \& Pham Trong Anh, 1992).

The published information about Con Dao bats is most controversial. Van Peenen (Van Peenen et al., 1970) mentioned five species in four families. Later, one more species, Hipposideros bicolor Temminck, 1834, was added to the list (Dang Huy Huynh et al., 1994). However, only few years later, G.V. Kuznetsov (Kuznetsov, 2000) observed the mammalian fauna of the Vietnamese coastal islands and enlarged the Con Dao bat fauna to twelve species. Some of them were mentioned on a completely unclear ground. Therefore, partly due to Kuznetsov's publications, the composition of the Archipelago bat fauna in following checklists (Borissenko \& Kruskop, 2003; Kuznetsov, 2006; Dang Ngoc Can et al., 2008) looks far too big for such small island. In our opinion, some of the earlier bat records could be mistaken, being either based on wrong identifications, or on wrong taxonomic interpretations of island populations. For instance, the island report of Rhinolophus lepidus (Borissenko \& Kruskop, 2003; most probably the same bat was listed by Vu Dinh Thong et al. (2010) as $R$. pusillus) was based on a misidentification of the diverse morphotype of $R$. chaseni (Kruskop, 2011). Only four species were collected by Vu Dinh Thong (Vu Dinh Thong et al., 2010) from the Con Dao Islands, including Kerivoula cf. hardwickii Horsfield, 1824 which had not been reported for the archipelago before. However, this author failed to confirm any of the previous doubtful records, such as Hipposideros ater, $H$. diadema, Rhinolophus luctus, $R$. thomasi and some others. The most recent incorrect association of a species record with the Con Dao is- lands concerns Murina cyclotis Dobson, 1872 (Nguyen Truong Son et al., 2015). In the mentioned publication the site 42 should have to be located nearby the Binh Chau Nature Reserve, Ba Ria - Vung Tau Province in mainland Vietnam, but was erroneously placed in Con Dao.

In 1984, forested areas of Con Son and neighbouring islands were declared the protected national forest areas. In 1993, this initiative was further developed by establishing the Con Dao National Park, which covers the land area of approximately $60 \mathrm{~km}^{2}$ and includes Con Son and neighboring islands, together with a coastal marine zone of around $140 \mathrm{~km}^{2}$ (Hayward \& Giang Thuy Huu Tran, 2014). The National Park provides protection to the areas of tropical forest (both evergreen and deciduous) that are home to a number of plant and animal species that are unique to the archipelago. The park's coastal zone is also home to an abundant variety of marine animals, including turtles and dugongs.

A short biodiversity survey of the Con Son Island was carried out in 2010 by the Joint Vietnam-Russian Tropical Research and Technological Centre. This paper presents results of its mammal survey, including a complete annotated list of the mammals.

\section{Material and methods}

Fieldworks were conducted in the Con Dao National Park (Ba Ria - Vung Tau Province) from 26 May to 12 June, 2010. The base camp was located on the Con Son Island, at the National Park Headquarters, near Con Dao Town.

The mammal fauna was assessed by a combination of field observations, indirect observations (tracks, feces, vocalizations), and the trapping of bats and nonvolant small mammals. Different biotopes located westward and eastward of the So Ray Plantation, forest area near the Ong Dung Station at the western coast of Island, vicinities of Nui Chua Mt., areas in the northern part of island (the airport area) and sites near the Con Dao Town were surveyed. A total of 16 field sites (located from the sea level up to $470 \mathrm{~m}$ a.s.l.) in the central and northern part of Con Son Island was surveyed (see Table 1). Map of the surveyed sites is shown in Figure 1.

Different types of traps were used, as follows: (1) pitfall traps, i.e. plastic glasses $(13 \times 9 \mathrm{~cm})$ and baskets $(25 \times 20 \mathrm{~cm})$, buried flush in the ground; (2) large $(11 \times 11 \times 25 \mathrm{~cm})$ cage live-traps, each with a bait piece of apples and a foam-rubber piece saturated with honey and vegetable oil that were replaced every $2-3$ days. A total of 1237 trap-nights for the pitfall traps and 683 trap-nights the cage-traps was conducted for (Table 1). Cage-traps were placed on the ground and trunks of fallen and lopsided trees and bamboo, lianas and branches situated 1 to $7 \mathrm{~m}$ above the ground.

Bat observations were conducted visually with the help of electric lanterns, and acoustically by the use of 
Table 1. Details of small mammal trapping in the central and northern parts of Con Son Island (May-June 2010).

\begin{tabular}{|c|c|c|c|c|c|}
\hline \multirow{2}{*}{$\begin{array}{l}\text { Trapline } \\
\text { No. }\end{array}$} & \multirow[b]{2}{*}{ Description of habitats } & \multirow{2}{*}{$\begin{array}{l}\text { Coordinates, } \\
\text { elevation }\end{array}$} & \multirow[b]{2}{*}{ Date } & \multicolumn{2}{|c|}{ Amount of trap-nights } \\
\hline & & & & $\begin{array}{l}\text { Cage } \\
\text { traps }\end{array}$ & $\begin{array}{l}\text { Pitfall } \\
\text { traps }\end{array}$ \\
\hline 1 & $\begin{array}{l}\text { Green fences near } \\
\text { Headquarters of the National } \\
\text { Park }\end{array}$ & $\begin{array}{l}08^{\circ} 41^{\prime} 31^{\prime \prime} \mathrm{N} \\
106^{\circ} 36^{\prime} 17^{\prime \prime} \mathrm{E} \\
2 \text { m a.s.l. }\end{array}$ & $27-30.05 .2010$ & 30 & - \\
\hline 2 & $\begin{array}{l}\text { Dense reed beds near } \\
\text { Headquarters of the National } \\
\text { Park }\end{array}$ & $\begin{array}{l}08^{\circ} 41^{\prime} 31^{\prime \prime} \mathrm{N} \\
106^{\circ} 36^{\prime} 17^{\prime \prime} \mathrm{E} \\
2-5 \text { m a.s.l. }\end{array}$ & $2-11.06 .2010$ & - & 141 \\
\hline 3 & $\begin{array}{l}\text { Slightly disturbed forest at the } \\
\text { north-western slope in the } \\
\text { central part of the island }\end{array}$ & $\begin{array}{l}08^{\circ} 42^{\prime} 10^{\prime \prime} \mathrm{N} \\
106^{\circ} 35^{\prime} 30^{\prime \prime} \mathrm{E} \\
80 \text { m a.s.l. }\end{array}$ & $29.05-02.06 .2010$ & 40 & - \\
\hline 4 & $\begin{array}{l}\text { Slightly disturbed forest at the } \\
\text { north-western slope in the } \\
\text { central part of the island }\end{array}$ & $\begin{array}{l}08^{\circ} 42^{\prime} 11^{\prime \prime} \mathrm{N} \\
106^{\circ} 35^{\prime} 08^{\prime \prime} \mathrm{E} \\
25 \mathrm{~m} \text { a.s.l. } \\
\end{array}$ & $29.05-2.06 .2010$ & 40 & 40 \\
\hline 5 & $\begin{array}{l}\text { Slightly disturbed forest at the } \\
\text { north-western slope in the } \\
\text { central part of the island }\end{array}$ & $\begin{array}{l}08^{\circ} 42^{\prime} 03^{\prime \prime} \mathrm{N} \\
106^{\circ} 35^{\prime} 11^{\prime \prime} \mathrm{E}, \\
85 \text { m a.s.l. }\end{array}$ & 29.05-2.06.2010 & 40 & 40 \\
\hline 6 & $\begin{array}{l}\text { Slightly disturbed forest at the } \\
\text { north-western slope in the } \\
\text { central part of the island }\end{array}$ & $\begin{array}{l}08^{\circ} 41^{\prime} 57^{\prime \prime} \mathrm{N} \\
106^{\circ} 35^{\prime} 13^{\prime \prime} \mathrm{E} \\
110 \text { m a.s. }\end{array}$ & $30.05-2.06 .2010$ & - & 45 \\
\hline 7 & $\begin{array}{l}\text { Slightly disturbed forest at the } \\
\text { south-eastern slope in the } \\
\text { central part of the island }\end{array}$ & $\begin{array}{l}08^{\circ} 41^{\prime} 16^{\prime \prime} \mathrm{N} \\
106^{\circ} 35^{\prime} 20^{\prime \prime} \mathrm{E}, \\
40-75 \mathrm{~m} \text { a.s. } 1 \text {. }\end{array}$ & $29.05-7.06 .2010$ & 165 & 245 \\
\hline 8 & $\begin{array}{l}\text { So Ray Plantation: grassy areas } \\
\text { along forest edge }\end{array}$ & $\begin{array}{l}08^{\circ} 41^{\prime} 28^{\prime \prime} \mathrm{N} \\
106^{\circ} 35^{\prime} 20^{\prime \prime} \mathrm{E} \\
210 \mathrm{~m} \text { a.s.l. }\end{array}$ & $30.05-7.06 .2010$ & - & 170 \\
\hline 9 & $\begin{array}{l}\text { Mixed dipterocarp and } \\
\text { Casuarina forest on the sand } \\
\text { ground near Con Dao Town }\end{array}$ & $15 \mathrm{~m}$ a.s.l. & $6-11.06 .2010$ & 62 & 8 \\
\hline 10 & $\begin{array}{l}\text { Large reed beds around ponds, } \\
\text { near Con Dao Town }\end{array}$ & $5 \mathrm{~m}$ a.s.1. & $7-11.06 .2010$ & 40 & - \\
\hline 11 & $\begin{array}{l}\text { Moist primary forest at the } \\
\text { northern slope of Nui Chua Mt. }\end{array}$ & $\begin{array}{l}08^{\circ} 42^{\prime} 49^{\prime \prime} \mathrm{N} \\
106^{\circ} 37^{\prime} 13^{\prime \prime} \mathrm{E} \\
250 \text { m a.s.l. }\end{array}$ & $3-11.06 .2010$ & 80 & 167 \\
\hline 12 & $\begin{array}{l}\text { Moist primary forest with } \\
\text { Alocasia at the northern slope } \\
\text { of Nui Chua Mt. }\end{array}$ & $\begin{array}{l}08^{\circ} 42^{\prime} 41^{\prime \prime} \mathrm{N} \\
106^{\circ} 37^{\prime} 03^{\prime \prime} \mathrm{E} \\
300 \text { m a.s.l. }\end{array}$ & $3-11.06 .2010$ & 80 & 92 \\
\hline 13 & $\begin{array}{l}\text { Moist primary forest at the } \\
\text { northern slope of Nui Chua Mt. }\end{array}$ & $\begin{array}{l}08^{\circ} 42^{\prime} 48^{\prime \prime} \mathrm{N} \\
106^{\circ} 37^{\prime} 07^{\prime \prime} \mathrm{E} \\
270 \text { m a.s.l. }\end{array}$ & $6-11.06 .2010$ & - & 45 \\
\hline 14 & $\begin{array}{l}\text { Bamboo thickets with dense } \\
\text { leaf litter at the northern slope } \\
\text { of Nui Chua Mt. }\end{array}$ & $\begin{array}{l}08^{\circ} 42^{\prime} 42^{\prime \prime} \mathrm{N}, \\
106^{\circ} 36^{\prime} 42^{\prime \prime} \mathrm{E}, \\
380 \mathrm{~m} \text { a.s.l. }\end{array}$ & $3-11.06 .2010$ & 80 & 124 \\
\hline 15 & $\begin{array}{l}\text { Slightly disturbed forest at the } \\
\text { Nui Chua summit }\end{array}$ & $\begin{array}{l}08^{\circ} 42^{\prime} 20^{\prime \prime} \mathrm{N}, \\
106^{\circ} 36^{\prime} 24^{\prime \prime} \mathrm{E}, \\
470 \mathrm{~m} \text { a.s.l. }\end{array}$ & $28.05-5.06 .2010$ & & 80 \\
\hline 16 & $\begin{array}{l}\text { Bush thickets in northern part } \\
\text { of the island (airport area). }\end{array}$ & $\begin{array}{c}08^{\circ} 43^{\prime} 13^{\prime \prime} \mathrm{N}, \\
106^{\circ} 38^{\prime} 08^{\prime \prime} \mathrm{E}, \\
1 \text { m a.s.l. }\end{array}$ & $9-11.06 .2010$ & 26 & 40 \\
\hline & & & Total & 683 & 1237 \\
\hline
\end{tabular}




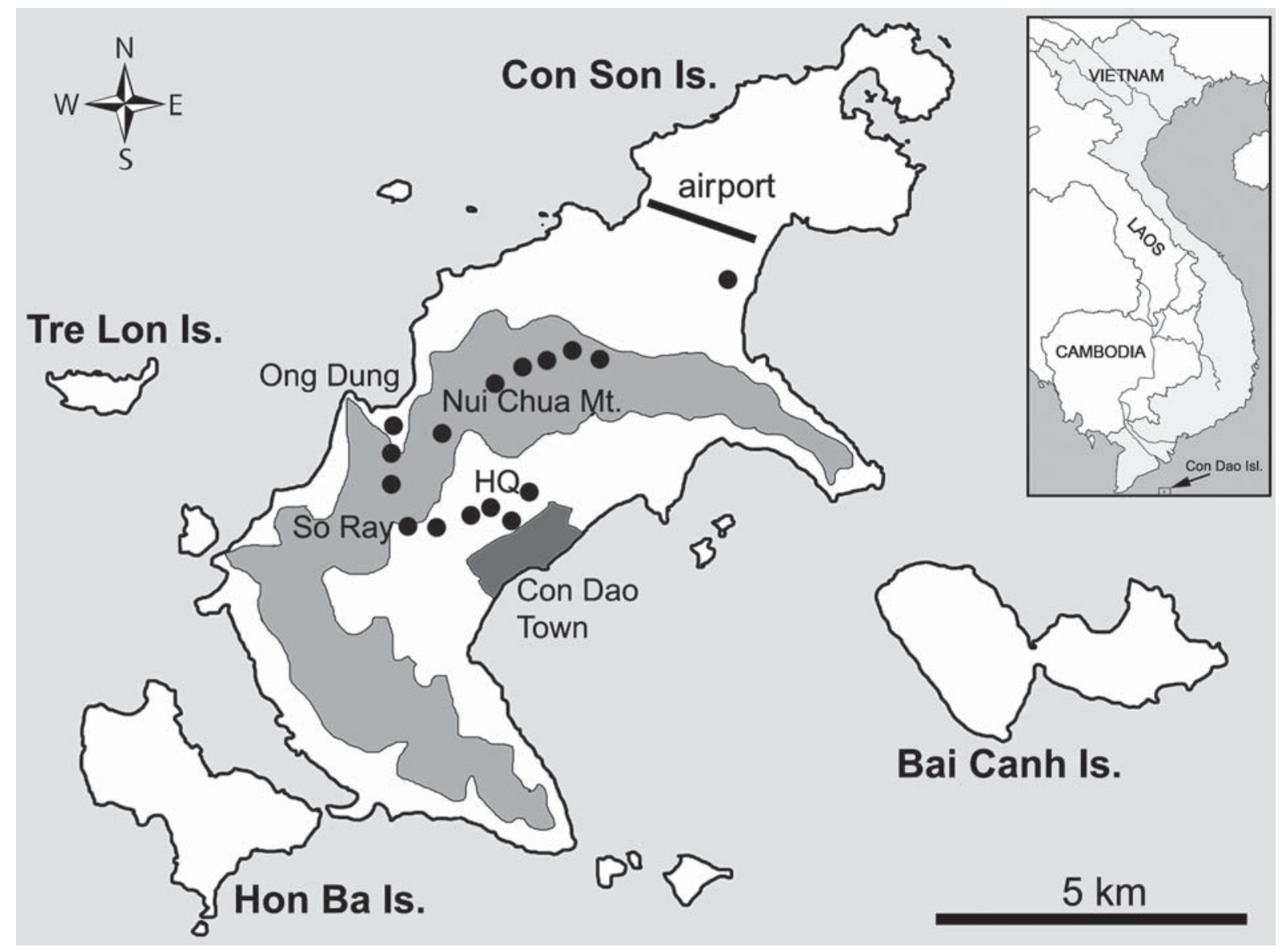

Fig. 1. Collecting localities (black circles) on the Con Son Island. Gray shadings show the main mountain range of the Con Son Island. HQ - the Headquarters of the Con Dao National Park.

narrow-band heterodyne ultrasound detector with frequency deviation function D230 (Pettersson Elektronik $\mathrm{AB}$, Sweden). Most observations were held in the first half of the night, from the sunset (c. $\left.17^{50}\right)$ till the $20^{30}$ $21^{30} \mathrm{PM}$, or in the morning hours before sunrise (from $3^{40}$ to $6^{10} \mathrm{AM}$ ). For capturing alive bats standard technique of crossing bat flying paths by the nylon mist-nets (size 10×4 m) was used (Kunz \& Kurta, 1990; Borissenko \& Kruskop, 2003) together with the hand net or "flap-trap" (Borissenko, 1999). It is necessary to mention that an unpredictably high density of Hipposideors grandis somewhat restricted the use of mist-nets (since a large number of caught animals caused considerable damage to the net), which was compensated by collecting by hand nets.

The standard external body measurements (head and body length, tail length, hind foot length, ear length) were taken. For bats, the forearm and tibia lengths were also measured. Weight was taken in grams. Voucher specimens of each species were taken for confirmation of the record and further comparison with museum collections because a correct identification of some species in the field is impossible. Most specimens were preserved in $70 \%$ ethanol. Tissue samples for genetic studies were taken from some trapped specimens or from wing membranes of alive bats and stored in $96 \%$ ethanol. Also, helminthological samples were taken from selected specimens, and some ectoparasites were collected, including bat parasitic flies from the families Streblidae and Nycterebiidae. Except for voucher specimens, all trapped mammals were released. Voucher specimens were catalogued and studied at the Zoological Institute Russian Academy of Sciences (Saint Petersburg, Russia) and the Zoological Museum of the Moscow State University (Moscow, Russia, ZMMU). To clarify species identification and taxonomic relations of the Con Son bat populations, standard DNA barcode region (657 base pair 5' segment of the mitochondrial cytochrome oxidase subunit I (COI)) was sequenced for the available bat tissue samples in the Centre for Biodiversity Genomics (CBG), University of Guelph, Canada. Sequences are now available from the database of Barcoding of Life Data Systems (BOLD; www.boldsystems.org). 


\section{Results}

Based on visual records and more than 180 trapped specimens, we have confirmed the present occurrence of at least 17 mammal species on the Con Son Island, representing seven mammalian orders. The following account provides morphological characteristics and relevant taxonomic notes along with natural history information for each collected species. The nomenclature of mammals follows Wilson \& Reeder (2005) unless otherwise stated. An annotated list of all terrestrial mammal species reported from Con Son (29 in total) is presented in Table 2 .

\section{ORDER SCANDENTIA}

Family TUPAIIDAE

Tupaia belangeri (Wagner, 1841)

The northern tree-shrew is a common species that is widespread on the Con Son Island. Tree-shrews were found at all the studied sites except for the areas near human settlements. Most specimens were caught on the ground, large stones or fallen trees. Just a few specimens were trapped on tree branches at the height of about 1-2 m (see Fig. 2). The highest density of treeshrews was found at the south-eastern slope of the main mountain ridge (trapline \#7, see Table 1).
Taxonomic remarks. The Con Son tree-shrew was described as a distinct subspecies $T$. belangeri dissimilis (Ellis in Gray, 1860).

\section{ORDER LIPOTYPHLA}

Family SORICIDAE

Crocidura fuliginosa Blyth, 1855

The lipotyphlan fauna of the Con Dao Archipelago is very poor (Abramov et al., 2013). Previous studies (Van Peenen et al., 1970; Kuznetsov \& Pham Trong Anh, 1992) listed just two shrew species - Suncus murinus and Crocidura fuliginosa. The former species is often found in houses and dwellings (Van Peenen et al., 1970). The latter is known from the Archipelago from only two specimens. An adult male (USNM 357348) was caught at the side of the trail (80 $\mathrm{m}$ a.s.1.) leading to Nui Chua Mt. (Van Peenen et al., 1970), the second specimen (ZMMU S-144368) was collected by G.V. Kuznetsov in 1987 from the small Bai Canh Island.

Despite considerable trapping efforts (more than 1200 pitfall trap-days, see Table 1), we collected only one specimen of this species. An adult female was trapped in the vicinity of Nui Chua Mt. (at $205 \mathrm{~m}$ a.s.1.). This is large and long-tailed shrew (head and body length $90 \mathrm{~mm}$, tail length $71 \mathrm{~mm}$ ). The mtDNA analysis suggests that the specimen from the Con Son Island belongs to C. fuliginosa (Abramov et al., 2012).

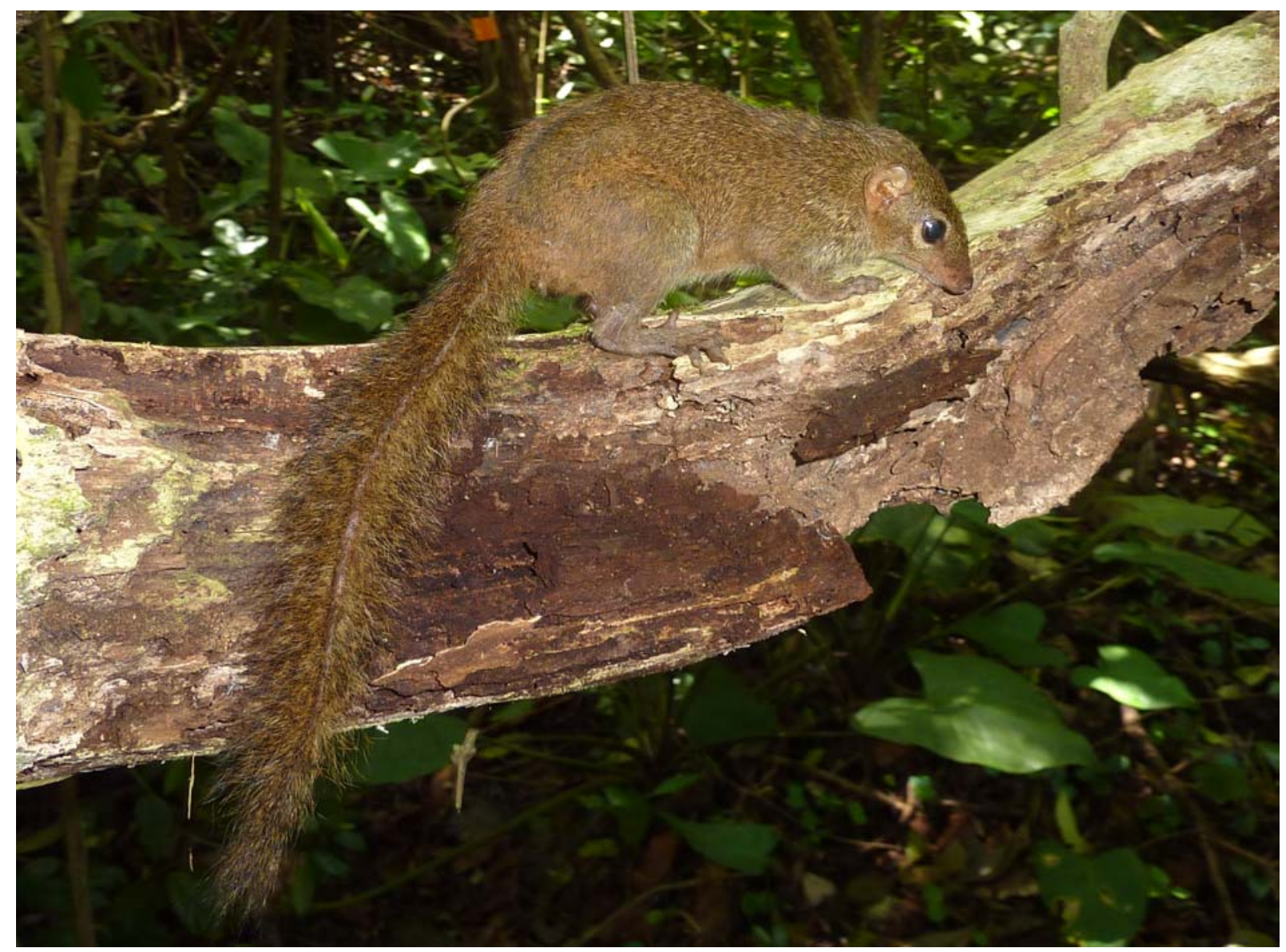

Fig. 2. Northern tree-shrew Tupaia belangeri. 
Table 2. An annotated list of the mammal species recorded from the Con Son Island.

\begin{tabular}{|c|c|c|c|c|}
\hline \multirow{2}{*}{ No. } & \multirow{2}{*}{ Species } & \multicolumn{2}{|c|}{ Our data (2010) } & \multirow{2}{*}{ Remarks } \\
\hline & & Observed & Collected & \\
\hline 1 & Tupaia belangeri & + & + & $\begin{array}{l}\text { Common species. Listed as Tupaia glis by } \\
\text { Van Peenen et al. (1970) }\end{array}$ \\
\hline 2 & Crocidura fuliginosa & - & + & Rare species \\
\hline 3 & Suncus murinus & - & - & $\begin{array}{l}\text { Four specimens were collected from the Con } \\
\text { Dao Town in } 1969 \text { (Van Peenen et al., 1970) }\end{array}$ \\
\hline 4 & Pteropus hypomelanus & + & - & Rare species \\
\hline 5 & Pteropus vampyrus & - & - & $\begin{array}{l}\text { Reported by Kuznetsov (2000) as visually } \\
\text { observed. Most likely this was a mistake, but } \\
\text { there is a possibility for occasional vagrants }\end{array}$ \\
\hline 6 & Macroglossus sobrinus & - & + & Rare species \\
\hline 7 & $\begin{array}{l}\text { Taphozous } \\
\text { melanopogon }\end{array}$ & - & - & $\begin{array}{l}\text { Unconfirmed report for the Bai Canh Island } \\
\text { (Kuznetsov, 2000), though there is small } \\
\text { possibility for occasional vagrants }\end{array}$ \\
\hline 8 & Rhinolophus chaseni & + & + & $\begin{array}{l}\text { Numerous species. Previously also reported as } \\
R . \text { borneensis (Dang Ngoc Can et al., 2008). } \\
\text { Most probably the same bat was erroneously } \\
\text { identified as } R \text {. thomasi, Rh. pusillus or } R \text {. } \\
\text { lepidus (e.g., Kuznetsov, 2000; Vu Dinh } \\
\text { Thong et al., 2010) }\end{array}$ \\
\hline 9 & Rhinolophus luctus & - & - & $\begin{array}{l}\text { Unconfirmed and doubtful report for the Bai } \\
\text { Canh Island (Kuznetsov, 2000) }\end{array}$ \\
\hline 10 & Hipposideros grandis & + & + & $\begin{array}{l}\text { The most abundant bat species. Listed as } H . \\
\text { larvatus neglectus by Van Peenen et al. }(1970) \\
\text { and as } H . \text { larvatus by Dang Ngoc Can et } \\
\text { al. }(2008)\end{array}$ \\
\hline 11 & Hipposideros galeritus & + & + & Recorded for the first time; rather common \\
\hline 12 & $\begin{array}{l}\text { Hipposideros } \\
\text { cineraceus }\end{array}$ & + & + & $\begin{array}{l}\text { Common species. Listed as Hipposideros } \\
\text { bicolor by Dang Huy Huynh et al. (1994) and } \\
\text { Kuznetsov (2000) and as H. ater by Dang } \\
\text { Ngoc Can et al. (2008) }\end{array}$ \\
\hline 13 & Hipposideros armiger & - & - & $\begin{array}{l}\text { Reported by Kuznetsov (2000) for the Bai } \\
\text { Canh Island as "captured", but no museum } \\
\text { specimens are available. }\end{array}$ \\
\hline 14 & Hipposideros diadema & - & - & $\begin{array}{l}\text { Highly doubtful report by Kuznetsov (2000), } \\
\text { made as "seen" }\end{array}$ \\
\hline 15 & Megaderma spasma & + & + & Common species \\
\hline 16 & Kerivoula hardwickii & + & + & Rare species \\
\hline 17 & Rattus germaini & + & + & $\begin{array}{l}\text { Common species. Listed as R. rattus germaini } \\
\text { by Van Peenen et al. (1970) }\end{array}$ \\
\hline 18 & Rattus exulans & - & - & $\begin{array}{l}\text { Few specimens collected near Con Dao Town } \\
\text { (Van Peenen et al., 1970) }\end{array}$ \\
\hline 19 & Rattus norvegicus & - & - & $\begin{array}{l}\text { Unconfirmed record from Le Xuan Canh } \\
(2004)\end{array}$ \\
\hline 20 & Niviventer huang & - & + & $\begin{array}{l}\text { Rare species. Listed as Rattus fulvescens by } \\
\text { Van Peenen et al. (1970) and as Niviventer } \\
\text { bukit by Le Xuan Canh (2004) }\end{array}$ \\
\hline 21 & Berylmys berdmorei & - & - & $\begin{array}{l}\text { One specimen collected in } 1969 \text { (Van Peenen } \\
\text { et al., 1970) }\end{array}$ \\
\hline 22 & Hylopetes spadiceus & - & - & $\begin{array}{l}\text { Two specimens collected in } 1969 \text { (Van Peenen } \\
\text { et al., 1970). Le Xuan Canh (2004) also listed } \\
\text { the second species - Hylopetes lepidus for the } \\
\text { island, but it is doubtful because H. lepidus is } \\
\text { distributed in Java and Borneo (Thorington \& } \\
\text { Hoffmann, 2005) }\end{array}$ \\
\hline 23 & Belomys pearsonii & - & - & $\begin{array}{l}\text { Unconfirmed record from Le Xuan Canh } \\
\text { (2004) }\end{array}$ \\
\hline 24 & Ratufa bicolor & + & - & Common species \\
\hline 25 & Callosciurus finlaysonii & + & + & Common species \\
\hline
\end{tabular}


Table 2 (continued).

\begin{tabular}{|c|c|c|c|c|}
\hline \multirow{2}{*}{ No. } & \multirow{2}{*}{ Species } & \multicolumn{2}{|c|}{ Our data (2010) } & \multirow{2}{*}{ Remarks } \\
\hline & & Observed & Collected & \\
\hline 26 & $\begin{array}{l}\text { Paradoxurus } \\
\text { hermaphroditus }\end{array}$ & + & - & $\begin{array}{l}\text { According to our data and published records } \\
\text { (Van Peenen et al., 1970), it is the only } \\
\text { viverrid species occurring on the islands. The } \\
\text { occurrence of Viverricula indica is not } \\
\text { confirmed }\end{array}$ \\
\hline 27 & Macaca fascicularis & + & - & Rare species \\
\hline 28 & Macaca arctoides & - & - & $\begin{array}{l}\text { Unconfirmed record from Le Xuan Canh } \\
\text { (2004) }\end{array}$ \\
\hline 29 & Lepus peguensis & + & - & $\begin{array}{l}\text { Common species. Listed as Lepus nigricollis } \\
\text { by Le Xuan Canh (2004) }\end{array}$ \\
\hline
\end{tabular}

Taxonomic remarks. Most researchers treated all large Crocidura from Indochina as $C$. fuliginosa (Heaney \& Timm, 1983; Jenkins et al., 2009). The recent DNA study (Bannikova et al., 2011) revealed that the large white-toothed shrews from northern Vietnam and southern China belong to a distinct species $C$. dracula. The occurrence of $C$. fuliginosa in the mainland Vietnam is still questionable (Abramov et al., 2012, 2013). The species' occurrence has only been confirmed for Con Son and Bai Canh islands of the Con Dao Archipelago.

Crocidura fuliginosa was described from central Myanmar (Blyth, 1855), so it is unclear whether this name can be applied to the Vietnamese taxon. The DNA-confirmed records of the Vietnamese haplogroup are known from Cameron Highland, Peninsular Malaysia (Bannikova et al., 2011) and Cardamom Mts, Cambodia (Eldridge et al., 2014).

\section{ORDER CHIROPTERA}

Bats constitute a significant part of our captures from and the island mammalian diversity on Con Son. Our bat records from the island were already published (Kruskop, 2011), therefore only a brief review thereof with some further comments on the taxonomy is provided.

\section{Family PTEROPODIDAE}

Pteropus hypomelanus Temminck, 1853

It is the largest bat species in the archipelago and one of the largest in Vietnam, inferior in size only to two other Vietnamese Pteropus species (Kruskop, 2013). The measured specimen (a subadult male) had the wingspan of about $75 \mathrm{~cm}$ and forearm of $122 \mathrm{~mm}$. A colour pattern of this individual was on the whole similar to the holotype of $P$. $h$. condorensis Peters, 1869 (the adult male ZMB-3945 in the collection of Museum für Naturkunde, Berlin). However, our individual was much paler from above, with more yellowish brown fur on its shoulders and head top and silver-gray upper fur on its back instead the almost black back in ZMB-3945. Most probably, these colour difference depend on the age of individuals.

$P$. hypomelanus seems to be not very numerous in the Con Dao Islands, though an estimation of their exact density cannot be done without special observa- tions. We assume that flying foxes of Con Dao do not form large aggregations and live solitary or in small groups and they can move between larger islands of the archipelago.

Taxonomic and conservation remarks. The Con Dao population was described as a distinct taxon $P$. hypomelanus condorensis, which is now accepted as a subspecies (Simmons, 2005). Although IUCN lists this species as least concern (Francis et al., 2008), the isolated Con Dao population, especially if its independent taxonomic status will be confirmed, could be at risk and require special attention.

\section{Macroglossus sobrinus K. Andersen, 1911}

This very small fruit bat (with forearm of only 42 $\mathrm{mm}$ ) seems to be uncommon on Con Son, and during our study was captured only once. We did not see this bat foraging anywhere and the only female was occasionally captured by a mist net in dense dry forest on a mountain slope. Probably these bats prefer such thick growth and avoid open places; this could be the reason for their rare captures.

Taxonomic remarks. As reported earlier, the Con Dao long-tongue bat is indistinguishable by COI $\mathrm{mtD}$ NA marker from the mainland specimens of M. sobrinus (Kruskop, 2011). This situation could be explained as a result of the possible ancient mtDNA introgression; a similar mtDNA identity in morphologically welldistinguished species is already known in the pteropodids of Africa (Nesi et al., 2011). On the other hand, we did not have a possibility to compare Con Son specimens with other $M$. minimus. So, there is still a chance that the Con Dao long-tongue bats decreased in their size recently (similarly to Hipposideros grandis and Rhinolophus chaseni), only resembling "true" M. minimus. A final conclusion is possible, when additional material has been collected and analyzed by their nuclear genes.

\section{Family RHINOLOPHIDAE}

Rhinolophus chaseni Sanborn, 1939

The small horseshoe bat, with the forearm length of 40.7-44.4 mm. This species was second in density (after $H$. grandis), counting slightly more than $24 \%$ of 
all captured bats (28 individuals). These bats were found in most of the observed habitats and were represented in most daily captures of the survey.

Taxonomic remarks. The taxonomic history of $R$. chaseni was described earlier (Kruskop, 2011). Island individuals are significantly smaller than their mainland conspecifics in both external and cranial measurements (Kruskop, 2013) and better resemble $R$. malayanus. Together with a shape variability of the connecting process, this has caused a number of hitherto misidentifications. Meanwhile, at least mtDNA have shown no difference between Con Son and mainland populations. A comparison of $23 \mathrm{COI}$ sequences taken from the BOLD projects "BM Bats of Southeast Asia" and "ABBSI Bats of Southeast Asia Part 2" did not revealed even specific haplotypes which could distinguish individuals from Con Son, mainland part of Ba Ria - Vung Tau Province, Dong Nai and Tai Ninh provinces of Vietnam. Such low genetic diversity may indicate a recent extension of the species range in Southern Indochina and correspondingly a quite recent connection between Con Dao Islands and the mainland.

\section{Family HIPPOSIDERIDAE}

Hipposideros grandis G. Allen, 1936

The Con Dao intermediate leaf-nosed bat is a middle-size hipposiderid with forearm length of 53.8-57.6 $\mathrm{mm}$. This species was found to be most abundant bat on the Con Son Island, registered in almost all the studied habitats and areas; 32 captured individuals composed about $27 \%$ of all bats captures during the survey. Sometimes, up to 6-7 foraging bats of this species could be seen simultaneously in a beam of torch light. During the evening emergence, we calculated about 2000 animals definitely coming out the same day roost (mixed up with some other species, most probably H. cineraceus).

In the island bat assemblage, the intermediate leafnosed bat represents the main component of the aerial hawker niche. Apparently, due to the absence of pipistrelles, serotines or large aerial foraging Hipposideros, $H$. grandis maximally expanded the boundaries of its ecological space. In the island, this species uses a wide range of foraging biotopes and, apparently exploiting the resource which would be claimed by at least four or five bat species in continental communities. This seems to explain the high abundance of the species in Con Son Island.

Taxonomic remarks. The Con Dao intermediate leafnosed bat was described as a distinct subspecies, $H$. grandis consonensis Kruskop, 2015, based on the smaller size, dull coloration as compared to mainland populations and some genetic differences (Kruskop, 2015). Meanwhile, there are still some doubts in what could be a proper name for $H$. grandis itself. The whole group "larvatus" has a very complicated taxonomic history (Thabah et al., 2006; Kruskop, 2015) and a number of species as well as species borders in this complex remain uncertain yet. Since no genetic material has been studied from the type locality of $H$. grandis, there is not confidence in the association between this name and large "larvatus-like" Hipposideros from southern Indochina.

Hipposideros galeritus Cantor, 1846

The fawn leaf-nosed bat was reported on Con Dao Islands by us for the first time (Kruskop, 2011). Female and four males were captured and studied, most of them originated from the So Ray Plantation. Contrary to $R$. chaseni with which $H$. galeritus occupies similar foraging niches in Con Son, this bat usually avoids any open places and forage close to growth. Probably, the closer connection of $H$. galeritus with forest habitats allows both species to decrease the competition for food resources.

Taxonomic remarks. DNA barcodes of $H$. galeritus from Con Son form a compact haplogroup, most similar to some haplogroups from Dong Nai Province. The single prepared penial bone is on the whole similar to that of specimens from Dak Lak Province; the reported difference (Kruskop, 2014) could represent an individual variation.

\section{Hipposideros cineraceus Blyth, 1853}

The third species of leaf-nosed bats found on Con Son was much more numerous than $H$. galeritus. This corroborates the opinion that this bat, being a perchhunter and probably gleaner, does not compete for resources with $H$. galeritus and, more importantly, with two other most abundant island bat species. In our captures this small (forearm 34.5-36.0 mm) Hipposideros was represented by six females and five males.

Taxonomic remarks. It is highly unlikely that two similar species of Hipposideros could co-exists in such a small archipelago. Thus, the records of $H$. bicolor from these islands (e.g., Nguyen Chi Thanh et al., 2004) are likely to belong to $H$. cineraceus. The DNA barcodes from Con Son form a very compact haplogroup, most similar to the haplogroups from Cat Tien National Park, Dong Nai Province.

As compared to $H$. grandis and $R$. chaseni, we did not find any reliable difference in the external morphology between $H$. galeritus and $H$. cineraceus from Con Dao and their mainland conspecifics.

The three hipposiderids confirmed for Con Son represent somewhat different niches: the middle-size unspecialized aerial hawker (H. grandis), the forestdwelling small aerial hawker (H. galeritus) and the very small perch-hunter/gleaner (H. cineraceus) (Fig. 3 ). It is worth noticing that all three forms represent the small size class, even $H$. grandis is much smaller than its mainland conspecifics. This could be related to the possible insular limitation of food resources.

\section{Family MEGADERMATIDAE}

Megaderma spasma (Linnaeus, 1758)

These medium size bats are quite common in Con Son, considering a smaller average population density of megadermatids compared to aerial hawking insect bats. Only three individuals were netted and studied in hands, though visually this bat was observed much more frequently, including the finding of two day roosts (Kruskop, 2011; Fig. 4). 


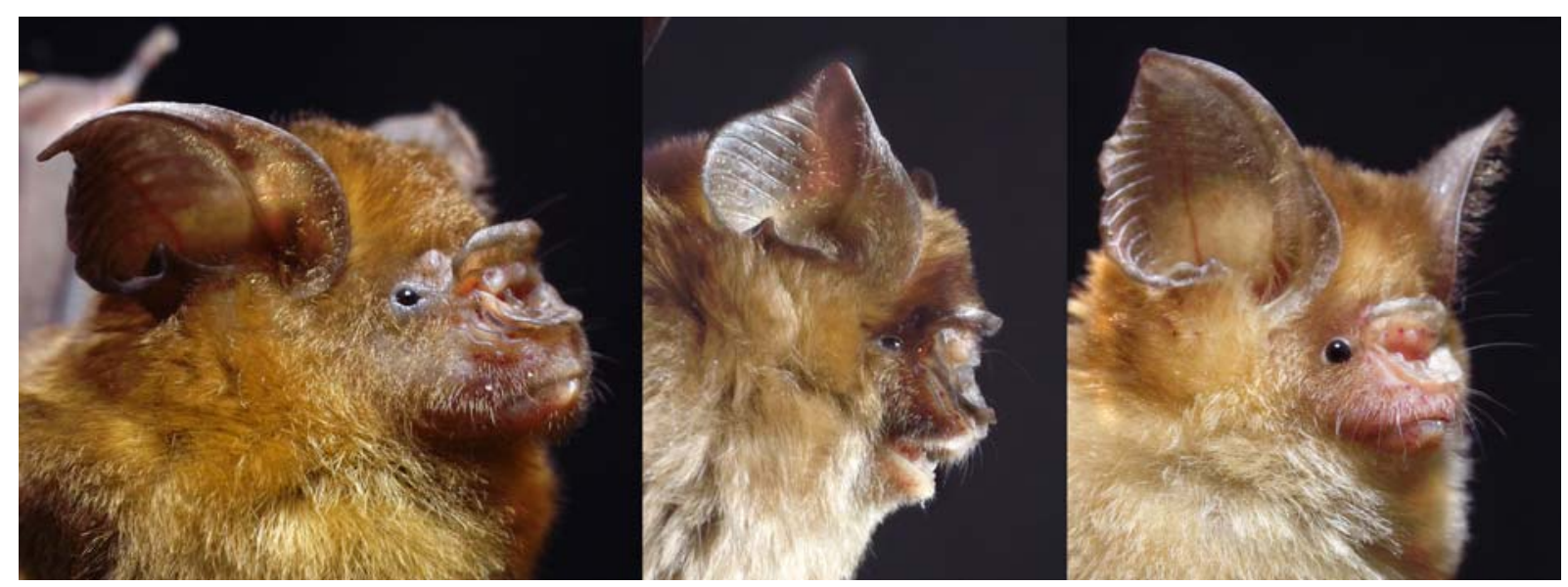

Fig. 3. Three round-leaf bats occurring on the Con Son Island (left to right): intermediate, Hipposideros grandis; fawn, $H$. galeritus; and least, H. cineraceus.

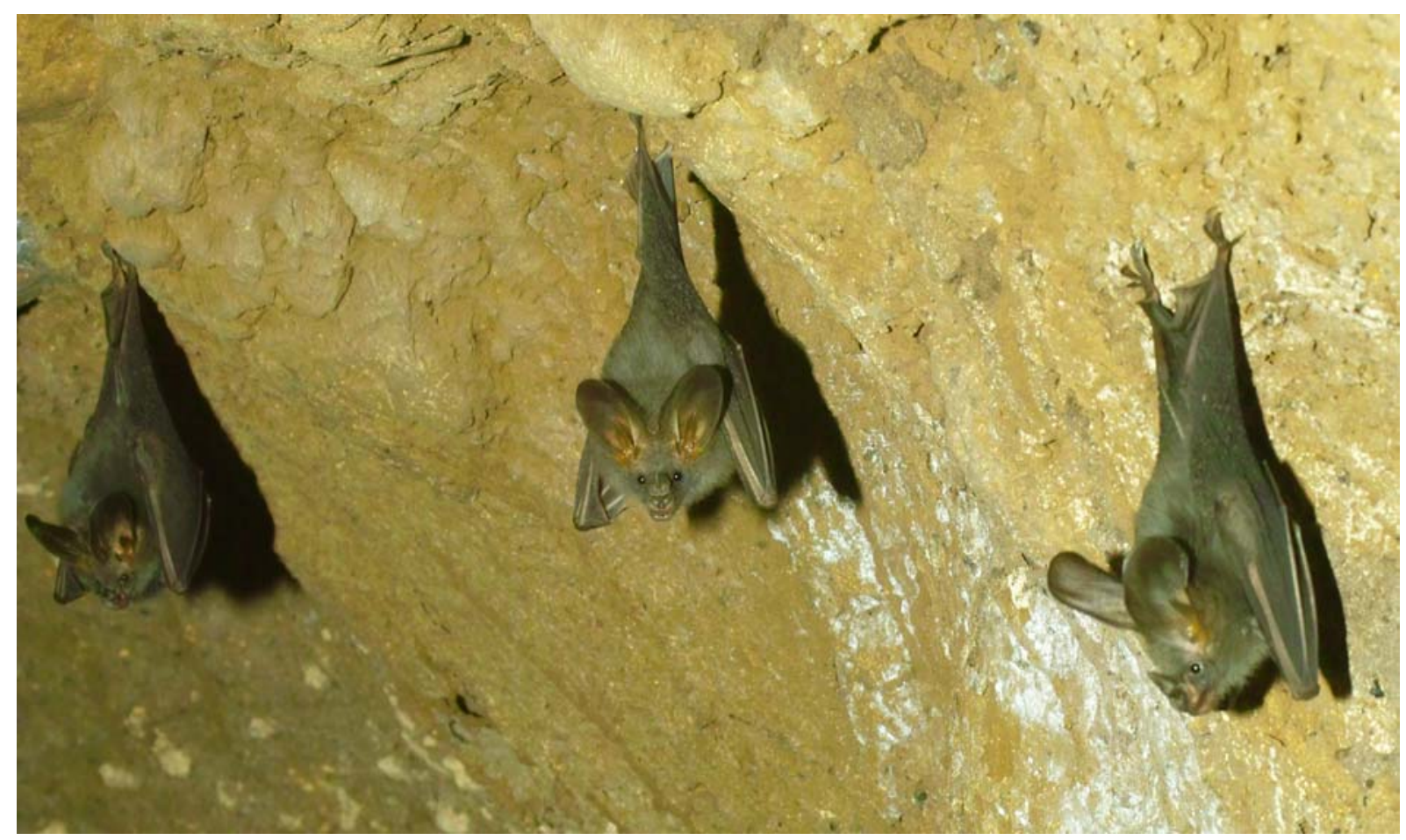

Fig. 4. Lesser false vampire bats Megaderma spasma roosting in the cavity.

Taxonomic remarks. The measured males had the forearm length of around $53.6 \mathrm{~mm}$ - close to the lower limit of size variation in the Vietnamese M. spasma. There is a possibility that this presumably sedentary bat may form a separated race in Con Dao. Unfortunately we failed to extract DNA from Con Son Megaderma specimens that would suffice for an analysis, and therefore cannot comment on their intraspecific relations.

Family VESPERTILIONIDAE

Kerivoula hardwickii (Horsfield, 1824)

This bat was reported by $\mathrm{Vu}$ Dinh Thong et al. (2010) from the Con Dao Archipelago for the first time, and later confirmed by Kruskop (2011). It is the only vespertilionid species in the island fauna. All our captures were made from the So Ray Plantation. That place, due to mosaic forest landscape and the presence of permanent water source, definitely represents a key site for local bat diversity; a reliable part of our bat findings was made there.

Taxonomic remarks. Based on DNA barcodes, a taxonomic heterogeneity of $K$. hardwickii s. lato was supposed (Francis et al., 2010), and our data correspond with that assumption (Kruskop, 2011). In a recent phylogenetic analysis of the $K$. hardwickii species complex (Kuo et al., 2017), the presence of at least 


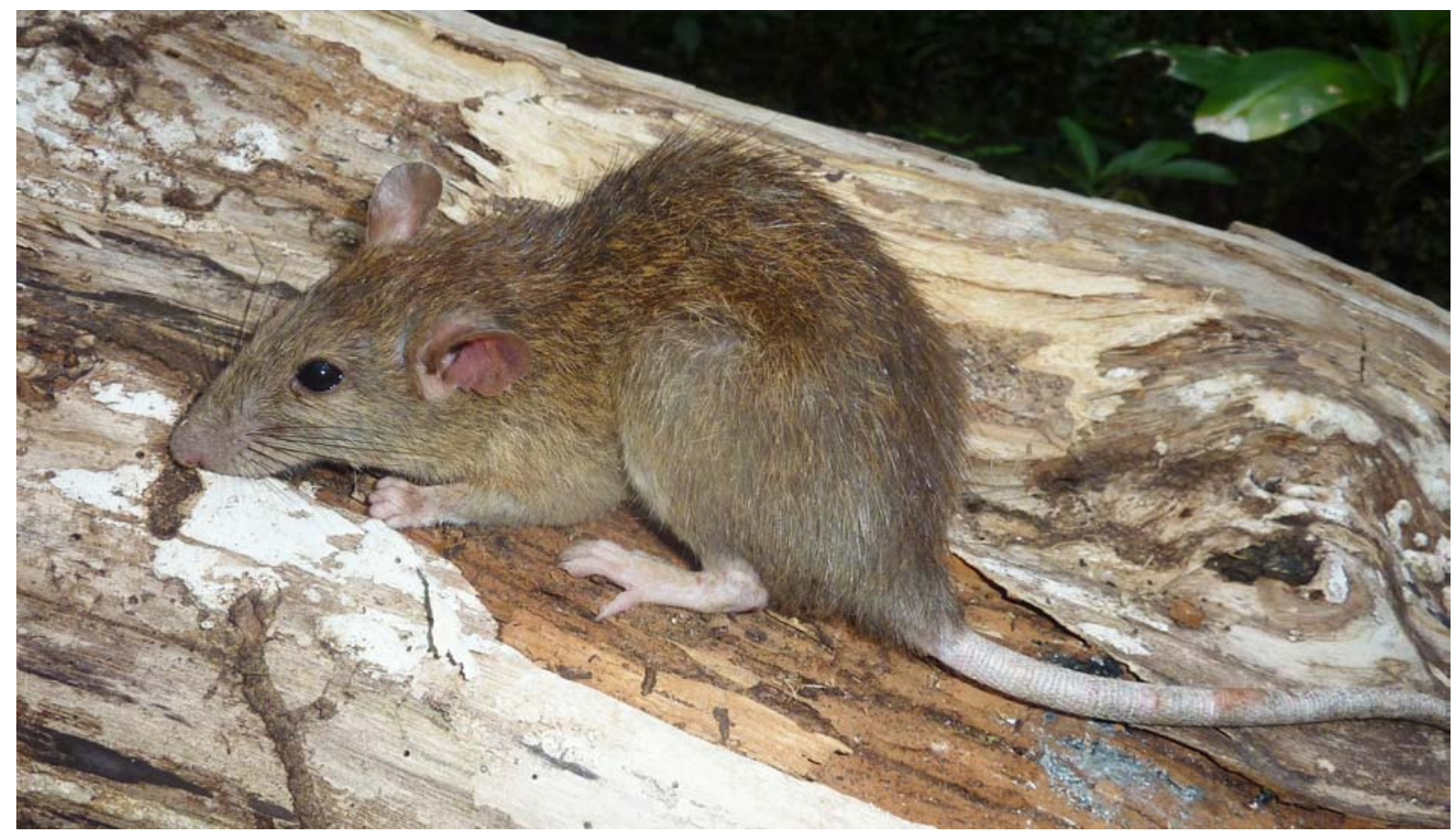

Fig. 5. Germaine rat Rattus germaini.

three cryptic species was shown. According to the COI tree topology, the Con Son specimens belong to the "clade C" which is associated with K. hardwickii s. str., to which specimens from Vietnamese lowland forests also belong.

\section{ORDER RODENTIA}

Family MURIDAE

Rattus germaini (Milne-Edwards, 1872)

Rats of medium size. Body length on the average is $197.7 \mathrm{~mm}(185-215 \mathrm{~mm}, n=39)$, tail length -220.6 $\mathrm{mm}(198-244 \mathrm{~mm}, n=34)$. The tail is dark, unicoloured, somewhat longer than the body (on average, $112 \%$ of the body length). Females have five pairs of mammae. The back is grayish red, the belly is whitish, quite contrasting with the coloration of the back and sides (Fig. 5).

The Germaine rat is the most numerous rodent species in the Con Son Island, the occurrence was more than $50 \%$ of all trapped non-volant mammals. This species was recorded in all studied biotopes, including human settlements. The animals were caught by cagetraps set up both on the ground and on tree branches, at heights up to $7 \mathrm{~m}$.

Many of the trapped rats $(27 \%)$ were young specimens. Pregnant females accounted for $12 \%$ of all trapped females. It seems that the breeding season of $R$. germaini on the Con Son Island is April.

Taxonomic remarks. The Rattus taxonomy is rather controversial. Many researchers (Pavlinov et al., 1995; Lunde \& Nguyen Truong Son, 2001; Musser \& Carleton, 2005; Dang Ngoc Can et al., 2008) treated many taxa of the "Asian type" rat of the "Rattus rattus group" from SE Asia, including $R$. germaini, as the single species Rattus tanezumi. According to these authors, $R$. tanezumi is widely distributed in Vietnam (Lunde \& Nguyen Truong Son, 2001; Dang Ngoc Can et al., 2008). Kuznetsov (2006) treated Rattus germaini as a distinct species that is endemic to Vietnam, occurring in coastal islands of southern Vietnam (Con Son, Bai Canh and Tho Chu Island - located in Gulf of Thailand). Rattus germaini was described from the Con Son Island (Milne-Edwards, 1872). Milne-Edwards named this form as "Mus Germani". It was an incorrect patronym named after Mr. Germain (see Milne-Edwards, 1872: 37), so the correct species name should be "germaini". An analysis of mitochondrial gene coxI (Balakirev \& Rozhnov, 2012) revealed that the haplotypes of Con Son Rattus were identical or very similar to those of rats from the mainland of southern Vietnam, Phu Quoc Island, Malacca, Java, Borneo and Sulawesi (see also Robins et al., 2007, 2010; Pages et al., 2010). Balakirev \& Rozhnov (2012) named these rats as $R$. tiomanicus Miller, 1900. However, the name Rattus germaini (Milne-Edwards, 1872) has a priority over $R$. tiomanicus, and we attribute this name for this southern haplogroup of Rattus. Two specimens from the Con Son Island (one from the vicinity of Con Dao Town, another from the site eastward of the So Ray Plantation) have the coxI haplotypes similar to that of $R$. tanezumi. It can be resulted from a possible hybridization between aboriginal $R$. germaini and introduced $R$. tanezumi, naturally distributed in northern parts of Thailand, Laos and Vietnam (Pages et al., 2010; Balakirev \& Rozhnov, 2012). These two specimens were morphologically indistinguished from other Rattus collect- 


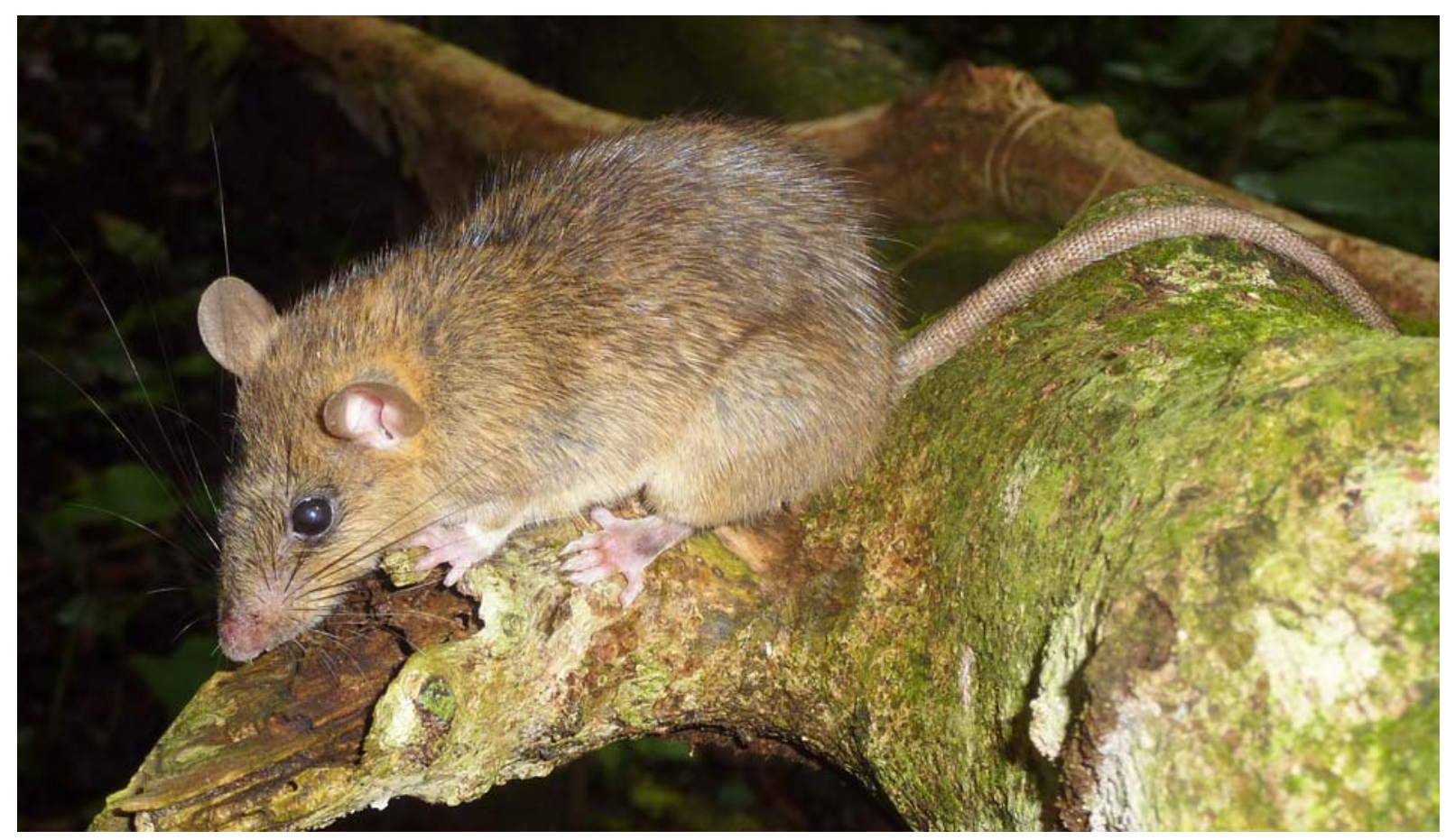

Fig. 6. Indomalayan niviventer Niviventer huang.

ed from the Con Son Island. Le Xuan Canh (2004) listed for Con Son Island two additional rat species, $R$. flavipectus and $R$. norvegicus, except for $R$. germaini. Recently, Rattus flavipectus was considered the synonym of $R$. tanezumi (Lunde \& Nguyen Truong Son, 2001; Musser \& Carleton, 2005; Dang Ngoc Can et al., 2008). The occurrence of synanthropic $R$. norvegicus in the Con Dao Archipelago was not confirmed during our survey.

Niviventer huang (Bonhote, 1905)

The only species of true forest rats of the genus Niviventer was collected in forest sites located eastward of the So Ray Plantation (one specimen) and in Nui Chua Mt. area (seven specimens). All animals were trapped by cage-trap set on the horizontal tree trunks and branches at the height of 1.5-3 $\mathrm{m}$ above the ground. One of the four females trapped in 4 June 2010 was pregnant and had 3 embryos.

Medium-sized rats, head and body length on the average is $151.3 \mathrm{~mm}(146-157 \mathrm{~mm}, n=4)$, tail length $177.0 \mathrm{~mm}(172-184 \mathrm{~mm}, n=3)$. Tail slightly bicoloured, a little bit longer than head and body length (115\% at average). Back colour reddish grey, venter white, demarcation between venter and side coloration is welldistinct (Fig. 6). Hind feet with dark stripe, which does not reach the base of digits.

Taxonomic remarks. The taxonomy of the genus Niviventer is rather controversial. Many taxa were described, but their validity and phylogenetic relationships remain unclear. Most researchers recognized four species of Niviventer in Vietnam: $N$. confucianus, $N$. tenaster, $N$. langbianis and $N$. fulvescens, with the latter species listed for the Con Son Island (Lunde \& Nguyen Truong Son, 2001; Pavlinov, 2003; Musser \& Carleton, 2005; Dang Ngoc Can et al., 2008). The recent taxonomic review based on the morphological and molecular analyses (Balakirev et al., 2012) revealed up to eight Niviventer species for the Vietnam territory. The authors treated a small niviventers of the fulvescens-group as two morphologically similar but genetically distinct species, $N$. huang and $N$. fulvescens. N. huang is widely distributed throughout Indochina, whereas $N$. fulvescens occurs in northern part of Indochina and southern China only. The niviventers of Con Son Island were genetically close to the populations from southern Vietnam (Balakirev et al., 2012), although slightly distinct from the continental conspecifics by their pelage coloration. This insular form was described under the name $N$. fulvescens condorensis Kloss, 1926 and perhaps represents a distinct subspecies.

Family SCIURIDAE

Callosciurus finlaysonii (Horsfield, 1824)

Finlayson's squirrels are distributed in southern and western Indochina (Thorington \& Hoffmann, 2005; Thorington et al., 2012). This species is listed for the southern and central parts of Vietnam, including Phu Quoc and Con Son islands (Lunde \& Nguyen Truong Son, 2001; Kuznetsov, 2006; Abramov et al., 2007). C. finlaysonii is common and abundant species on the Con Son Island. It is also numerous on the Phu Quoc Island located in Gulf of Thailand (see Abramov et al., 2007). There are just few records of $C$. finlaysonii in mainland Vietnam - in Kon Tum and Dak Lak provinces in the 


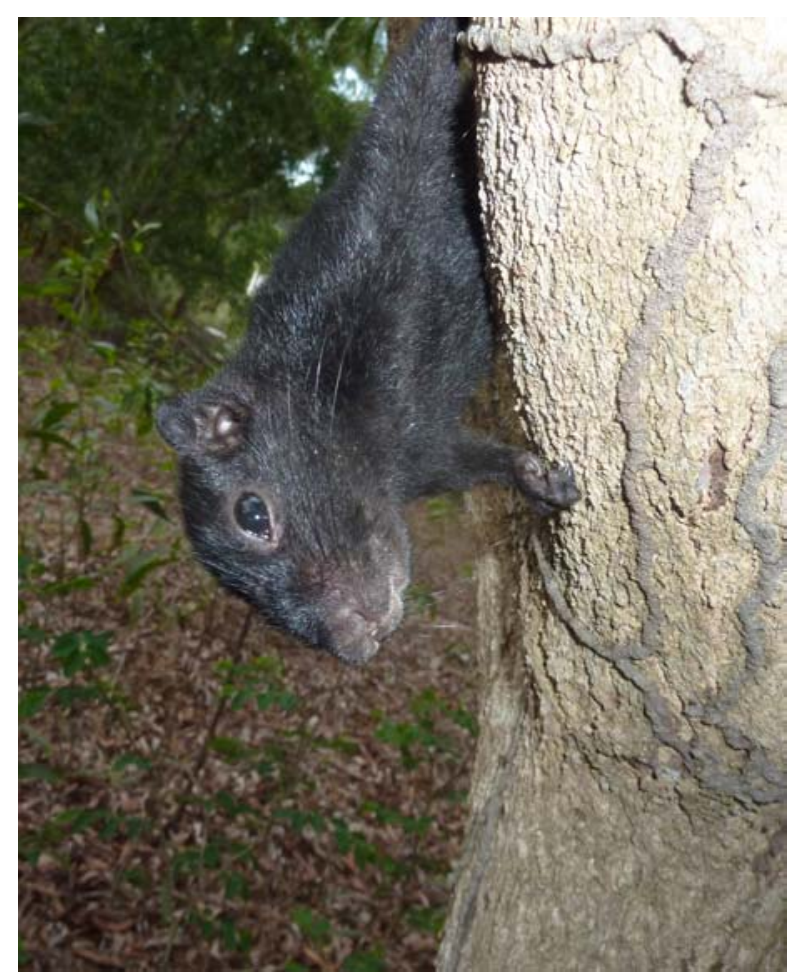

Fig. 7. Finlayson's squirrel Callosciurus finlaysonii.

central part of the country (Dang Ngoc Can et al., 2008). The species identification of mainland records needs to be confirmed.

Taxonomic remarks. This is a quite variable species, its pelage ranges from all white (nominotypical subspecies) to all red or even all black (Thorington et al., 2012). Squirrels from the Con Son Island have completely black pelage (Fig. 7). Usually, this form is treated as a distinct subspecies $C$. finlaysonii germaini (Milne-Edwards, 1867) (Thorington \& Hoffmann, 2005; Kuznetsov, 2006; Thorington et al., 2012).
Ratufa bicolor (Sparrman, 1778)

The giant squirrel is common and numerous on the Con Son Island. Squirrels were often observed in tree canopies during day excursions in the central part of the island.

Taxonomic remarks. The island is inhabited by the distinct subspecies $R$. bicolor condorensis Kloss, 1921, which differs from continental squirrels in a smaller size.

\section{ORDER CARNIVORA}

Family VIVERRIDAE

Paradoxurus hermaphroditus Pallas, 1777

Feces of the common palm civets were often found on the forest trails, fallen trees and large stones. A few times animals were observed during night excursions around the So Ray Plantation and along the trail to the Ong Dung Station.

According to our data and published records (Van Peenen et al., 1970), P. hermaphroditus is the only wild Carnivora species occurring on the Con Son Island. However, some publications also listed the small Indian civet Viverricula indica for the island (Darevsky et al., 1991; Kuznetsov \& Pham Trong Anh, 1992; Le Xuan Canh, 2004; Dang Ngoc Can et al., 2008). There are no museum specimens to confirm the latter record.

\section{ORDER PRIMATES}

Family CERCOPITHECIDAE

Macaca fascicularis Raffles, 1821

It is a common and widespread in Indochina monkey species. In Vietnam, the crab-eating macaque is found everywhere in forests, plantations and near human settlements. On the Con Son Island, we observed small groups and solitary specimens in the central part of the island (near the So Ray Plantation and in forest around the Ong Dung Station). A group of macaques, including three females with cubs, constantly inhabited the So Ray Plantation (Fig. 8).
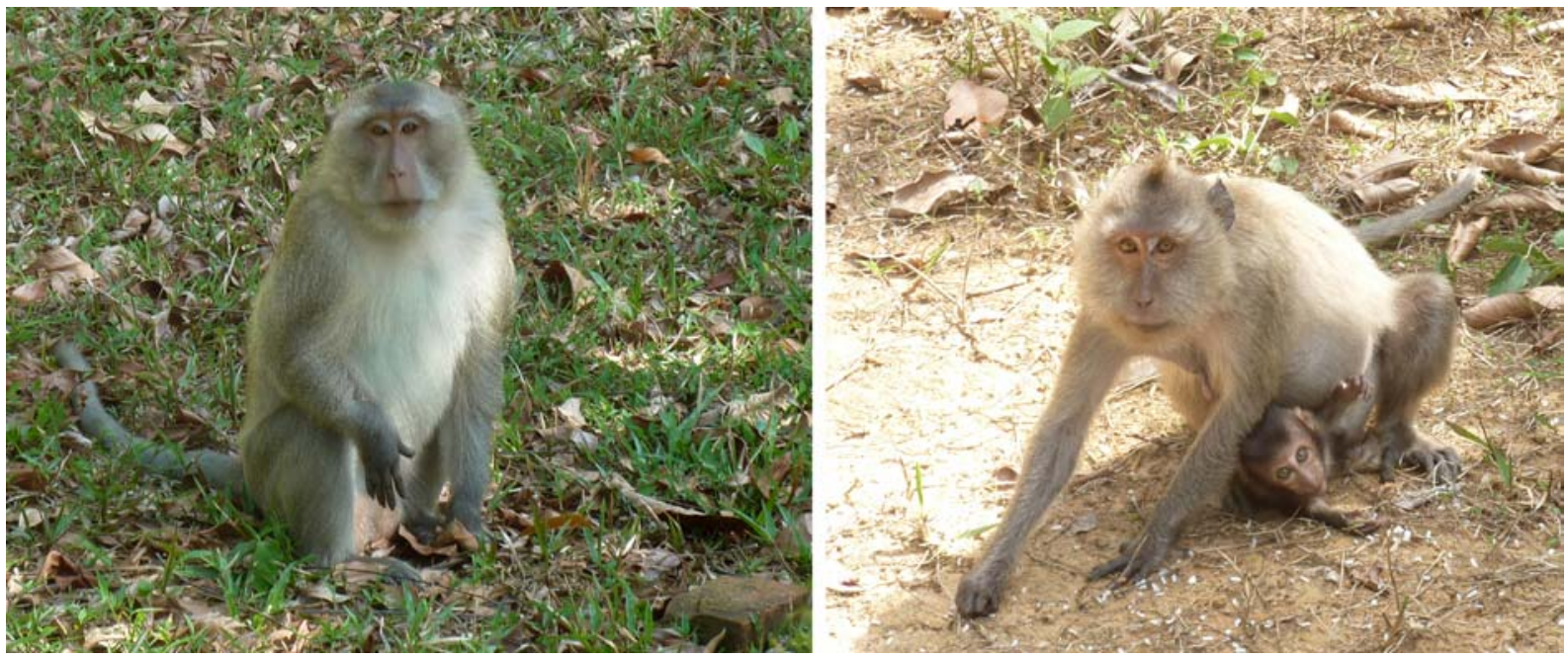

Fig. 8. Crab-eating macaque Macaca fascicularis in So Ray Plantation. 


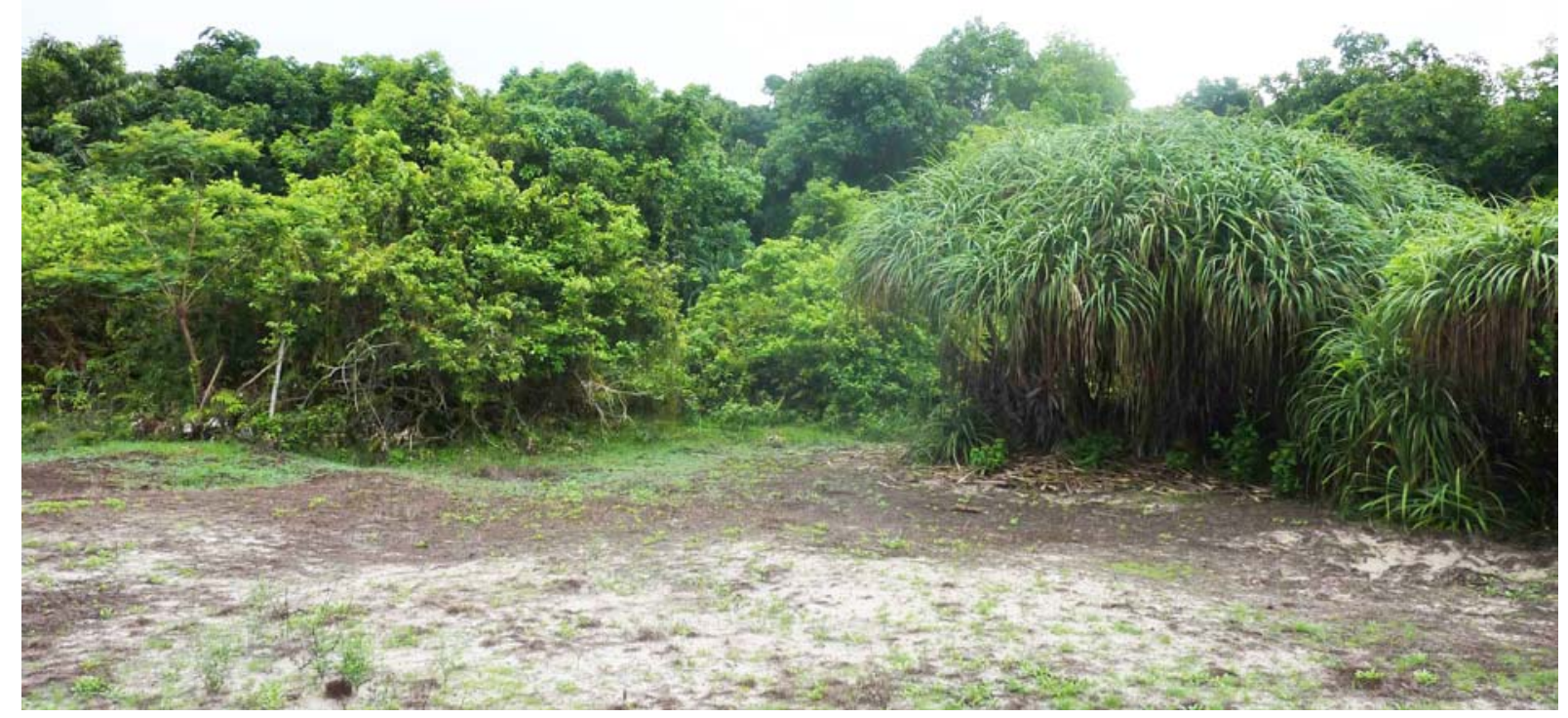

Fig. 9. Bush thickets in northern part of Con Son Island are typical habitats of Burmese hare Lepus peguensis.

Taxonomic remarks. Macaques from the Con Son Island were described as a distinct subspecies $M$. fascicularis condorensis Kloss, 1926.

\section{ORDER LAGOMORPHA}

Family LEPORIDAE

Lepus peguensis Blyth, 1855

The Burmese hares are rather numerous in bush thickets in the northern part of the island. Their footprints were often found on sandy plains near the airport area (Fig. 9).

\section{Conclusion}

The Con Dao Archipelago is situated relatively close to the mainland and its mammalian fauna is similar to that of southern Vietnam, but has some peculiarities. The number of species of non-volant mammals on the Con Son Island is less than that of the mainland supporting the historical-legacy hypothesis for terrestrial mammal distribution on coastal islands (Lawlor, 1986; Patterson \& Atmar, 1986). Many taxa represent distinct subspecies, and some (e.g., Callosciurus finlaysonii, Crocidura fuliginosa) have not yet been recorded from the continental part of Vietnam. Mammal fauna of the Con Son Island is characterized by a low species diversity and a high density of common species, such as Hipposideros grandis, Rhinolophus chaseni, Callosciurus finlaysonii, Rattus germaini, Tupaia belangeri, and Ratufa bicolor. The phenomenon of density compensation refers to a higher than mainland densities of island species that is linked to the lower overall richness of the island assemblage, and is often suggested to indicate a form of competitive release (Whittaker \& Fernandez-Palacios, 2007).
Similar to non-volant mammals, the bat assemblage of the Con Dao Archipelago has a proportionally lower species diversity. For comparison, in coastal forests near the Binh Chau Nature Reserve in the mainland part of Ba Ria - Vung Tau Province, the local bat assemblage accounts for more than 15 species (Kruskop, 2013). Such low diversity definitely corresponds to a smaller area of suitable biotopes and an insufficient overall productivity of the Con Dao natural environment. Another important factor which restricts the bat diversity seems to be an impossibility for forest species to make seasonal migrations and to avoid adverse conditions in particular seasons.

On the basis of the aforementioned reasons, it is highly unlikely that there are bat species on the archipelago that have not been seen by us. For example, the occurrence of large leaf-nosed bats such as Hipposideros armiger and especially the forest-dwelling $\mathrm{H}$. diadema which were reported by Kuznetsov \& Pham Trong Anh (1992) is highly unlikely; the markedly more adaptive $H$. grandis, with its extremely high local abundance, simply would not leave enough food resources for their populations. However, there is a possibility that in the recent past local conditions were friendlier for bats. Some species could occur on Con Dao as gradually declining populations, which became extinct only recently, in part due to anthropogenic changes of the island environment. Yet, in the case of large flying foxes and some species with high long-distance flight ability (like Chaerephon, Taphozous or Saccolaimus), there is some possibility for occasional vagrants.

A comparative analysis of the faunal assemblages of coastal islands and the taxonomic diversity of island mammals make it possible to look into the formation and evolution of island ecosystems. Many of these questions are related to changing sea levels during the 
Pleistocene and concomitant appearing of land bridges. Throughout the Pleistocene the drastic changes in the SE Asian landscape occurred as a result of sea level variations. In that time the islands of Con Dao Archipelago, as well as other coastal islands of Vietnam, were connected to the mainland (Voris, 2000). Temporary land bridges between the mainland and insular regions provided biotic migrations from the mainland to the archipelago (Heaney, 1986). The main configurations of the Vietnamese islands were formed during the Riss-Wurm (Sangamon) transgression with the rise of sea level up to 8-10 $\mathrm{m}$ above datum (Korotky et al., 1995). Along with other issues, this means that the isolation of the island is not too long for local populations to become highly divergent from their mainland conspecifics. Some of the rodent species (Rattus germaini, Niviventer huang) from the Con Son Island are genetically rather similar to their mainland conspecifics and probably represent recent colonization events. The same is true to some bat species (Hipposideros cineraceus, H. galeritus, Kerivoula hardwickii). In the case of Rhinolophus chaseni, the absence of even slightly divergent island haplogroup indicates a possibility for a very recent connection between Con Dao and mainland populations, at least for bats.

We have not found any support for previous suggestions about the Malayan origin of some Con Dao bats (Van Peenen et al., 1970). On the contrary, our data suggest recent connections with the mainland conspecifics for the majority of Con Dao species (Kruskop, 2011). However, the existence of some other faunal elements, such as Crocidura fuliginosa and Callosciurus finlaysonii, on the Con Dao islands could be evidence for the earlier Pleistocene colonization events when these territories of SE Asia presented part of a large land area during the low sea level time. The similar presence of some Malayan faunal elements that are not found or rare on the mainland in the Archipelago was supposed for other groups of animals: e.g., some butterflies demonstrate relations with their Bornean congenerics (Moulton, 1923). Likewise, some pigeon species occurring on the Islands are not found in mainland Indochina (Robson, 2008).

ACKNOWLEDGMENTS. We are grateful to the administration of the Con Dao National Park and the director Dr. Le Xuan Ai for providing an opportunity to carry out the surveys in the Park. Our field studies in Vietnam were possible due to the support of the Joint Vietnam-Russian Tropical Research and Technological Centre. We would like to express our thanks to A.N. Kuznetsov, Nguyen Dang Hoi, M.V. Kalyakin, A.B. Vassilieva, N.A. Poyarkov and all expedition members for their great help and scientific expertise during fieldworks. We are grateful to the anonymous referees for their valuable comments on an earlier draft of this manuscript. D.V. Logunov (Manchester Museum, UK) is thanked for improving the English of the final draft. This work was supported in part by the Russian Foun- dation for Basic Research (grants 16-04-00085a and 17-04-00689a). The study of bats was performed in line with State theme of scientific work of the ZMMU (AAAA-A16-116021660077-3).

\section{References}

Abramov A.V., Bannikova A.A. \& Rozhnov V.V. 2012. White-toothed shrews (Mammalia, Soricomorpha, Crocidura) of coastal islands of Vietnam // Zookeys. Vol.207. P.37-47.

Abramov A.V., Kalinin A.A. \& Morozov P.N. 2007. Mammal survey on Phu Quoc Island, southern Vietnam // Mammalia. Vol.71. No.1. P.40-46.

Abramov A.V., Dang Ngoc Can, Bui Tuan Hai \& Nguyen Truong Son. 2013. An annotated checklist of the insectivores (Mammalia, Lipotyphla) of Vietnam // Russian Journal of Theriology. Vol.12. No.2. P.57-70.

Balakirev A.E. \& Rozhnov V.V. 2012. Contribution to the species composition and taxonomic status of some Rattus inhabiting Southern Vietnam and Sundaland // Russian Journal of Theriology. Vol.11. No.1. P.33-45.

Balakirev A.E., Abramov A.V. \& Rozhnov V.V. 2012. Taxonomic revision of Niviventer (Rodentia, Muridae) from Vietnam: a morphological and molecular approach // Russian Journal of Theriology. Vol.10 (for 2011). No.1. P.1-26.

Bannikova A.A., Abramov A.V., Borisenko A.V., Lebedev V.S. \& Rozhnov V.V. 2011. Mitochondrial diversity of the white-toothed shrews (Mammalia, Eulipotyphla, Crocidura) in Vietnam // Zootaxa. Vol.2812. P.1-20.

Bates P.J.J. \& Harrison D.L. 1997. Bats of the Indian Subcontinent. Sevenoaks: Harrison Zoological Museum. 258 p.

Blyth E. 1855. Report for May Meeting, 1855 // Journal of the Asiatic Society of Bengal. Vol.24. No.4. P.359-363.

Borissenko A.V. 1999. [A mobile trap for capturing bats in flight] // Plecotus et al. Vol.2. P.10-19 [in Russian with English summary].

Borissenko A.V. \& Kruskop S.V. 2003. Bats of Vietnam and Adjacent Territories. An Identification Manual. Moscow: GEOS. 203 p.

Corbet G.B. \& Hill J.E. 1992. The Mammals of the Indomalayan Region. Oxford: Oxford University Press. 488 p.

Csorba G., Ujhelyi J. \& Thomas N. 2003. Horseshoe Bats of the World (Chiroptera: Rhinolophidae). Bishop's Castle: Alana Books. $160 \mathrm{p}$.

Dang Huy Huynh, Dao Van Tien, Cao Van Sung, Pham Trong Anh, Hoang Minh Khien. 1994. [Checklist of Mammals in Vietnam]. Hanoi: Science and Technics. 168 p. [in Vietnamese]

Dang Ngoc Can, Endo H., Nguyen Truong Son, Oshida T., Le Xuan Canh, Dang Huy Phuong, Lunde D.P., Kawada S.I., Hayashida A. \& Sasaki M. 2008. [Checklist of Wild Mammal Species of Vietnam]. Hanoi: Institute of Ecology and Biological Resources. 400 p. [in Vietnamese]

Darevsky I.S., Ponomarenko A.G. \& Kuznetsov G.V. 1991. [Zoogeography of coastal islands of Vietnam] // Priroda. No.9. P.42-48 [in Russian].

Duncan J.F. \& Van Peenen P.F.D. 1971. Karyotypes of ten rats (Rodentia: Muridae) from Southeast Asia // Caryologia. Vol.24. P.331-346. 
Duncan J.F., Van Peenen P.F.D. \& Ryan P.F. 1970. Somatic chromosomes of eight mammals from Con Son Island, South Vietnam // Caryologia. Vol.23. P.173-181.

Eldridge M.D.B., Meek P.D. \& Johnson R.N. 2014. Taxonomic uncertainty and the loss of biodiversity on Christmas Island, Indian Ocean // Conservation Biology. Vol.28. No.2. P. $572-579$.

Francis C., Rosell-Ambal G., Bonaccorso F., Heaney L., Molur S. \& Srinivasulu C. 2008. Pteropus hypomelanus // The IUCN Red List of Threatened Species 2008: e.T18729A8511932.

Francis C.M., Borisenko A.V., Ivanova N.V., Eger J.L., Lim B.K., Guillen-Servent A., Kruskop S.V., Mackie I. \& Hebert P.D. 2010. The role of DNA barcodes in understanding and conservation of mammal diversity in Southeast Asia // PloS ONE. Vol.5. No.9. P.1-12.

Gray J.E. 1860. Early notice of the Tupaia found in Pulo Condore // The Annals and Magazine of Natural History. Ser.3. Vol.5. P.71.

Hadi T.R., Carney W.P., Van Peenen P.F.D. \& Hull W.B. 1977. Laelapid mites (Acari: Mesostigmata) from mammals of South Vietnam // Journal of Medical Entomology. Vol.13. No.4-5. P.587-590.

Hayward P \& Giang Thuy HuuTran. 2014. At the edge: heritage and tourism development in Vietnam's Con Dao Archipelago // Journal of Marine and Island Cultures. Vol.3. No.2. P.113-124.

Heaney L.R. 1986. Biogeography of mammals in SE Asia: estimates of rates of colonization, extinction and speciation // Biological Journal of the Linnean Society. Vol.28. P.127-165.

Heaney L.R. \& Timm R.M. 1983. Systematics and distribution of shrews of the genus Crocidura (Mammalia: Insectivora) in Vietnam // Proceedings of the Biological Society of Washington. Vol.96. P.115-120.

Jenkins P.D., Lunde D.P. \& Moncrieff C.B. 2009. Chapter 10. Descriptions of new species of Crocidura (Soricomorpha: Soricidae) from mainland Southeast Asia, with synopses of previously described species and remarks on biogeography // Voss R.S. \& Carleton M.C. (eds.). Systematic Mammalogy: Contributions in Honour of Guy G. Musser. Bulletin of the American Museum of Natural History. No.331. P.356-405.

Kloss C.B. 1921. The Pulo Condore group and its mammals // Journal of the Natural History Society of Siam. Vol.4. No.2. P.73-83

Koopman K.F. 1994. Chiroptera: Systematics. Handbook of Zoology. Vol.8. Mammalia, part 60. Berlin-New York: Walter de Gruyter. 217 p.

Korotky A.M., Razjigaeva N.G., Ganzey L.A., Volkov V.G., Grebennikova T.A., Bazarova V.B. \& Kovalukh N.N. 1995. Late Pleistocene-Holocene coastal development of islands off Vietnam // Journal of Southeast Asian Earth Sciences. Vol.11. No.4. P.301-308.

Kruskop S.V. 2011. New data on the bat fauna of Con Dao Islands // Russian Journal of Theriology. Vol.10. No.2. P.37-46.

Kruskop S.V. 2013. Bats of Vietnam. Checklist and an Identification Manual. Second edition, revised and supplemented. Biodiversity of Vietnam series. Moscow: KMK Scientific Press. 300 p.
Kruskop S.V. 2014. The bacula of some bat species from Indochina: rhinolophoids (Chiroptera: Rhinolophidae, Hipposideridae) // Plecotus et al. Vol.17. P.3-17 [in Russian with English summary].

Kruskop S.V. 2015. Dull and bright: cryptic diversity within the Hipposideros larvatus group in Indochina (Chiroptera: Hipposideridae) // Lynx, nová série (Praha). Vol.46. P.29-42.

Kunz T.H. \& Kurta A. 1990. Capture methods and holding devices // Kunz T.H. (ed.). Ecological and Behavioral Methods for the Study of Bats. Washington: Smithsonian Institution Press. P.1-29.

Kuo H.-C., Soisook P., Csorba G., Wang C.-N. \& Rossiter S.J. 2017. A taxonomic revision of the Kerivoula hardwickii complex (Chiroptera: Vespertilionidae) with the description of a new species // Acta Chiropterologica. Vol.19. No.1. P.19-39.

Kuznetsov G.V. 2000. Mammals of the coastal islands of Vietnam: zoogeographical and ecological aspects // Bonner Zoologische Monographien. Vol.46. P.357-366.

Kuznetsov G.V. 2006. [Mammals of Vietnam]. Moskva: KMK Scientific Press. 428 p. [in Russian]

Kuznetsov G.V. \& Pham Trong Anh. 1992. [Mammals of coastal islands of Vietnam (biogeographical and ecological aspects)] // Sokolov V.E. (ed.). [Zoological Studies in Vietnam]. Moskva: Nauka. P.182-197 [in Russian].

Lawlor T.E. 1986. Comparative biogeography of mammals on islands // Biological Journal of the Linnean Society. Vol.28. P.99-125.

Le Xuan Canh. 2004. [Forest animals of the Con Dao National Park] // Nguyen Chi Thanh et al. (eds.). [Animal and Plant Resources of the Forest in the Con Dao National Park]. Ho Chi Minh: Nha Xuat Ban Nong Nghiep. P.271-286 [in Vietnamese].

Lunde D. \& Nguyen Truong Son. 2001. An Identification Guide to the Rodents of Vietnam. New York: Center for Biodiversity and Conservation, American Museum of Natural History. 80 p.

Milne-Edwards M.A. 1867. Description de quelques especes nouvelles d'Ecureuils de l'ancien continent // Revue et Magasin de Zoologie. T.19. Ser.2. P.193-197.

Milne-Edwards M.A. 1872 (1868-1874). Recherches pour servir à l'histoire naturelle des mammifères 1868-1874. Paris: Masson. Vol.1, 394 p.; Vol.2, atlas.

Moulton J.C. 1923. On butterflies from Pulo Condore // Journal of Natural History Society of Siam. Vol.6. No.1. P.127-134.

Musser G.G. \& Carleton M.D. 2005. Superfamily Muroidea // Wilson D.E. \& Reeder D.M. (eds.). Mammal Species of the World: a Taxonomic and Geographic Reference. Third edition. Vol.2. Baltimore: Johns Hopkins University Press. P.894-1531.

Nesi N., Nakouná E., Cruaud C. \& Hassanin A. 2011. DNA barcoding of African fruit bats (Mammalia, Pteropodidae). The mitochondrial genome does not provide a reliable discrimination between Epomophorus gambianus and Micropteropus pusillus // Comptes Rendus Biologies. Vol.344. P.544-554.

Nguyen Chi Thanh, Tran Hop, Le Xuan Canh, Nguyen Ngoc Kieng, Le Xuan Ai \& Nguyen Duc Ngan (eds.). 2004. [Animal and Plant Resources of the Forest in the Con 
Dao National Park]. Ho Chi Minh: Nha Xuat Ban Nong Nghiep. 358 p. [in Vietnamese]

Nguyen Truong Son, Csorba G., Vuong Tan Tu, Vu Dinh Thong, Yi Wu, Harada M., Oshida T., Endo H. \& Motokawa M. 2015. A new species of the genus Murina (Chiroptera: Vespertilionidae) from the Central Highlands of Vietnam with a review of the subfamily Murininae in Vietnam // Acta Chiropterologica. Vol.17. No.2. P.201-232.

Pages M., Chaval Y., Herberteau V., Waengsothorn S., Cosson J.-F., Hugot J.-P., Morand S. \& Michaux J. 2010. Revisiting the taxonomy of the Rattini tribe: a phylogeny based delimitation of species boundaries // BMC Evolutionary Biology. Vol.10: 184.

Patterson B.D. \& Atmar W. 1986. Nested subsets and the structure of insular mammalian faunas and archipelagos // Biological Journal of the Linnean Society. Vol.28. P.6582.

Pavlinov I.Y. 2003. [Taxonomy of recent mammals] // Archives of Zoological Museum of Moscow State University. No.46. P.3-297 [in Russian].

Pavlinov I.Y., Yakhontov E.L. \& Agadjanyan A. K. 1995. [Mammals of Eurasia. I. Rodentia: systematic-geographic reference book] // Archives of Zoological Museum of Moscow State University. No.32. P.3-240 [in Russian].

Robins J.H., Hingston M., Matisoo-Smith E. \& Ross H.A. 2007. Identifying Rattus species using mitochondrial DNA // Molecular Ecology Notes. Vol.7. P.717-729.

Robins J.H., McLenachan P.A., Phillips M.J., McComish B.J., Matisoo-Smith E. \& Ross H.A. 2010. Evolutionary relationships and divergence times among the native rats of Australia // BMC Evolutionary Biology. Vol.10: 375.

Robinson H.C. \& Kloss C.B. 1921. Some birds from Pulo Condore // Journal of the Natural History Society of Siam. Vol.4. No.2. P.65-91.

Robson C. 2008. A Field Guide to the Birds of South-East Asia. London: New Holland Publisher Ltd. 544 p.

Rozhnov V.V. 1998. [The natural history investigations in Indochina: a retrospective review] // Korzun L.P. \& Kalyakin M.V. (eds.). [Materials of Zoological and Botanical Studies in Fan Si Pan Summit Area (North Vietnam)]. Moskva: Tropical Centre. P.11-66 [in Russian].
Sanborn C.C. 1939. Eight new bats of the genus Rhinolophus // Publications of Field Museum of Natural History (Zoology). No.24. P.37-43.

Simmons N.B. 2005. Order Chiroptera // Wilson D.E. \& Reeder D.M. (eds.). Mammal Species of the World: a Taxonomic and Geographic Reference. Third edition. Vol.1. Baltimore: Johns Hopkins University Press. P.312529.

Smith M.A. 1921. Reptiles and batrachians collected in Puolo Condore // Journal of the Natural History Society of Siam. Vol.4. No.2. P.93-97.

Thabah A., Rossiter S.J., Kingston T., Zhang S., Parsons S., Mya K.M., Akbar Z. \& Jones G. 2006. Genetic divergence and echolocation call frequency in cryptic species of Hipposideros larvatus s.l. (Chiroptera: Hipposideridae) from the Indo-Malayan region // Biological Journal of the Linnean Society. Vol.88. No.1. P.119-130.

Thorington R.W. \& Hoffmann R.S. 2005. Family Sciuridae // Wilson D.E. \& Reeder D.M. (eds.). Mammal Species of the World: a Taxonomic and Geographic Reference. Third edition. Vol.2. Baltimore: Johns Hopkins University Press. P.754-818.

Thorington, R.W., Koprowski J.L., Steele M.A. \& Whatton J.F. 2012. Squirrels of the World. Baltimore: Johns Hopkins University Press. 459 p.

Van Peenen P.F.D., Cunningham M.L. \& Duncan J.F. 1970. A collection of mammals from Con Son Island, Vietnam // Journal of Mammalogy. Vol.51. No.2. P.419-424.

Voris H.K. 2000. Maps of the Pleistocene sea levels in Southeast Asia: shorelines, river systems and time durations // Journal of Biogeography. Vol.27. P.1153-1167.

$\mathrm{Vu}$ Dinh Thong, Nguyen Truong Son, Dao Nhan Loi \& Pham Duc Tien. 2010. [An overview of bat research in Bai Tu Long and Con Dao national parks, with results from recent surveys] // Vietnamese Journal of Biotechnology. Vol.8. No.3A. P.999-1005 [in Vietnamese].

Wilson D.E. \& Reeder D.M. (eds.). 2005. Mammal Species of the World: a Taxonomic and Geographic Reference. Third edition. Vols.1-2. Baltimore: Johns Hopkins University Press. 2142 p.

Whittaker R.J. \& Fernandez-Palacios J.M. 2007. Island Biogeography: Ecology, Evolution, and Conservation. Second Edition. Oxford: Oxford University Press. 416 p. 